\title{
Adaptive Technology Training of Human Capital for the Mining Industry
}

\author{
Vadim Mikhalchenko ${ }^{1}$, and Irina Seredkina ${ }^{2}$ \\ ${ }^{1}$ Federal government budget educational institution of higher professional education "Kuzbass State \\ Technical University named TF Gorbachev", Institute of Economics and Management, Department of \\ Economics, 65000, Vesennaya st., 28, Kemerovo, Russia \\ ${ }^{2}$ Federal government budget educational institution of higher professional education "Kuzbass State \\ Technical University named TF Gorbachev", Institute of Economics and Management, Department of \\ Economics, 65000 Vesennaya st., 28, Kemerovo, Russia
}

\begin{abstract}
In the article the original method Quality Function Deployment in relation to the preparation of University specialists with higher education. The method is based on the process of a phased conversion of customer requirements in specific organizational, substantive and functional transformation of the technological process of the University. The ultimate goal of these reforms - training knowledge and skills which meet the requirements and expectations of the customers of universities enterprises of the mining industry.
\end{abstract}

\section{Introduction}

The business environment of modern life is characterized by a high level of dynamism, it is radically changing and demonstrates the ever-increasing pace of changes and innovations $[1,2]$. Used equipment and technologies become outdated extremely fast knowledge depreciates with high speed, competition forces businesses to constantly look for new solutions to reduce production costs and improve product quality, legislation and environmental requirements have become increasingly stringent.

In these conditions, the competitiveness of coal enterprises is largely determined by the quality of human capital. The knowledge of professionals, their creativity, ability to plan and implement technical, design and management solutions are becoming key success factor.

The main source of the formation of the corps of engineers in Russia are higher education institutions. However, as shown by the results of the study [3], modern universities in solving problems of providing the economy with qualified personnel, with adequate changes of the level of training of young specialists faced a number of problems. The system of training of young specialists, more recently, a completely satisfied consumer of products, no longer meets the requirements of modern society. Modern students, who will work with technologies of the mid-twentiethI century, still learning the ideas and technologies of the mid-twentieth century. As a consequence, the employer does not receive on a regular basis the "product" which would be fully consistent with his ideas about the high level of training in all aspects of the quality required for the implementation of the strategic goals of the organization [3]. In other words, the University needs to 
produce specialists with the knowledge level and depth which will allow them without additional "tuning" by employers, to successfully solve the problems of development in the new economic environment.

It is important to note that the modern Russian educational institutions have little connection with the consumers of their products and, as a consequence, a very modest idea of his expectations and needs. Moreover, these employers are not burdened with obligations and are not interested in communicating with high schools about what the latter should pay attention to when the formation of the desired qualities in the process of training specialists with higher education.

Thus, before the modern system of higher education there was a problem changes. The necessary structural transformation. The education system needs to become highly adaptive, capable of transmitting to the young generation of new knowledge at a speed higher than the speed of the changes of economic environment, development of techniques and technologies.

\section{Theory}

A product of the University is a specialist who has the knowledge he needs to achieve the goals of a business organization. Training goes through certain stages and can be considered as a technological process with a certain set of parameters, conditions, functions. Driving data components, designing a meaningful set of elements of the educational process, it is possible to obtain a product that would fully satisfy the needs of the employer.

One of the effective tools for solving this problem is the method Quality Function Deployment $[4,5,6]$.

The method is based on the process of a phased conversion of customer requirements into specific engineering parameters of the product, the organizational settings, the organization itself, with the result that full consumer satisfaction to product quality of the University.

A method of structuring the quality function includes four phases: "planning product", "product design", "designing process", "engineering production."

\section{Discussion}

In the first stage structuring the quality function (the"market study") team of experts (team of the University quality management) must identify key customers and using the selected methods (survey, analysis of statements in the media, complaints, etc.) to formulate and organize their basic requirements to quality of preparation of specialists with higher education (to hear the "voice of the consumer"). There is a "stretching" of the value of the product that required the consumer at the moment. As examples of such work include "profile quality" training of specialists with higher education for the enterprises of mining complex, formed in the result previously presented in [7] sociological research.

Upon further structuring of the quality function of the diversity of quality parameters to select the most important to the consumer. The rating of quality parameters can be generated using the results obtained in the course of applying the model of Kano $[8,9]$. The most important quality parameters is assigned a highest score rating, the less important quality parameters is the smallest score.

At the same time comparative rating of the University with its main competitors relative to the level of implementation of the identified quality parameters. This work is necessary to clarify the situation on what the consumer requirements of the position of the University 
is strong and is not necessary at this stage to spend time and resources to their satisfaction, and how customer requirements at the University are weak and urgently need to take additional measures.

The second stage of structuring the quality function ("product planning") solves the challenge through the implementation and improvement of any processes of the University can be met consumers ' expectations. In other words, you must answer the question "How to do this?" to obtain the product, consumers need.

If to consider the institution of a specialist with higher education as a "product" of the University, then difficulties arise with the definition of the technical parameters of this product: it cannot be measured, to test the strength of the material, to set the proportions of the components, etc. Therefore, quality parameters of higher education will be offered through the development of the processes of the University that contribute to their implementation and the formation of the expert (supporting processes), for example, to attract students to participate in research work, real practical training of young professionals in real organizations in a real work place, etc.

With further work on the structuring of the quality function you need to establish how much support the processes affect the level of implementation of quality parameters. Evaluation of correlation may be based on the experience of experts, the responses of consumers or the results of the experiments. The technical part of this work becomes the construction of the matrix "product design" (Fig.1) [10].

In the future of the variety to ensure fulfillment of the quality parameters of the processes are selected the most critical (priority) processes. This is achieved by calculating a measure of the "importance of relationships" and choosing the processes with the highest value of the importance of the relationship:

\section{$Z=\sum_{i=1}^{n}$ the strength of the relationship $\times$ rating user's quality settings}

In the demonstrated example, the processes of the University, highly influencing the formation valuable to an employer skills of specialists with higher education, are engaging students to participate in research and practical training of students.

It is additionally necessary to evaluate the degree of correlation between the supplying processes. Even if a process is less critical, but most critical process is closely associated with it, then it must also be taken into the list of priority. Correlations allow us to demonstrate the consequences when changing one of the characteristics of the product to understand which of the variables can be freely changed, and which are rigidly interconnected, and to change them requires special effort. When assessing correlation may be used expert opinion.

Another important element in the structuring of the quality function is the determination of key performance indicators and setting targets for implementation of the identified processes of the University to the embodiment of the "voice of the consumer" in the course of preparation of specialists with higher education. The target values of key performance indicators represent a sort of job design processes aimed at quality assurance in higher education. For example (Tab. 1), it is necessary to organize the work on conformity assessment of the basic educational programs and educational-methodical complexes of disciplines for the training of mining specialists of the main wishes and requirements of enterprises-employers. This takes into account that the University is a competitor could ensure the implementation of this process at a sufficiently high level. 
Table 1. The matrix design of the product.

\begin{tabular}{|c|c|c|c|c|c|}
\hline & \multicolumn{3}{|c|}{ Supporting processes } & \multirow[b]{2}{*}{\begin{tabular}{|c|}
$\begin{array}{c}\text { Evaluation of } \\
\text { competitors }\end{array}$ \\
$\begin{array}{c}\text { Competitivere } \\
\text { nt } 1\end{array}$ \\
\\
\end{tabular}} \\
\hline $\begin{array}{l}\text { quality Settings - "voice } \\
\text { of consumer" }\end{array}$ & 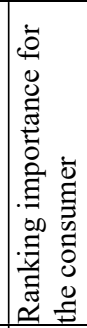 & 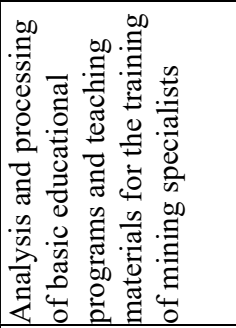 & 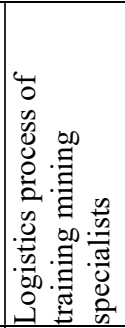 & 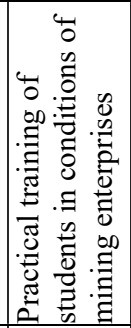 & \\
\hline $\begin{array}{l}\text { Professionally significant } \\
\text { qualities of personality }\end{array}$ & 5 & $\odot$ & & $\mathrm{O}$ & 2 \\
\hline Personal qualities & 5 & & & $\mathrm{O}$ & 5 \\
\hline $\begin{array}{l}\text { Special knowledge: } \\
\text { security issues, technical } \\
\text { calculations on the } \\
\text { production, Geology, } \\
\text { development of the project } \\
\text { and the subsequent } \\
\text { construction of underground } \\
\text { structures, geodesy, } \\
\text { forecasting of environmental } \\
\text { risks }\end{array}$ & 5 & $\odot$ & $\odot$ & $\odot$ & 4 \\
\hline $\begin{array}{l}\text { Practical training: } \\
\text { ability to work with modern } \\
\text { technology for mining } \\
\text { applications, from unmanned } \\
\text { aerial vehicles exploration }\end{array}$ & 4 & $\odot$ & $\odot$ & $\odot$ & 3 \\
\hline \multicolumn{2}{|c|}{$\begin{array}{l}\text { Absolute weight of importance } \\
\text { of the relationship }\end{array}$} & 135 & 81 & 111 & \\
\hline \multicolumn{2}{|c|}{$\begin{array}{l}\text { Relative weight of importance of } \\
\text { the relationship, } \%\end{array}$} & 41,3 & 24,8 & 33,9 & \\
\hline \multicolumn{2}{|c|}{ Key performance indicators } & 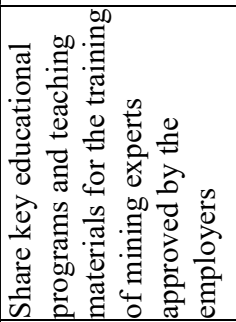 & 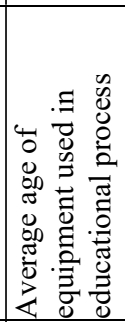 & 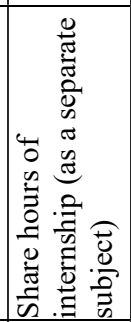 & \\
\hline \multicolumn{2}{|l|}{ Unit } & $\%$ & years & $\%$ & \\
\hline \multicolumn{2}{|c|}{$\begin{array}{l}\text { The current value of key } \\
\text { performance indicators to ensure } \\
\text { processes of the University }\end{array}$} & 15 & 15 & 1 & \\
\hline \multicolumn{2}{|c|}{$\begin{array}{l}\text { Values of key performance } \\
\text { indicators to ensure processes of } \\
\text { the University-competitor }\end{array}$} & 30 & 8 & 1 & \\
\hline \multicolumn{2}{|c|}{$\begin{array}{l}\text { the implementation of the } \\
\text { supporting processes of the } \\
\text { University }\end{array}$} & 30 & 5 & 15 & \\
\hline \multicolumn{2}{|l|}{$\begin{array}{l}\text { Evaluation of complexity of } \\
\text { implementation targets to ensure } \\
\text { processes }\end{array}$} & 6 & 6 & 8 & \\
\hline
\end{tabular}


$\odot$ - strong -9 points, $\mathrm{O}$ - average -3 points, $\Delta$ - weak -1 point

Defining critical (priority) processes to ensure the quality of training of specialists with higher education, and targets of their implementation, the work of a team of experts on quality control moves to the next stage structuring quality function - "design process".

Processes to ensure the quality of training of specialists with higher education and which need to be improved, are detailed with subprocesses.

The work involves identification of critical parameters of each subprocess and the choice of control system. Is the matrix of "design process" (Fig. 2). The priority of the processes to ensure the quality of training of specialists with higher education, are placed on the left side, and detailing their subprocesses are placed in the upper part of the matrix.

In the example (Tab. .2) it is clear that improving the practical training of students may require the development of basic educational programs in terms of planning of training students for real jobs in real businesses, methodical and consulting support of such training on the part of the faculty, establishing business contacts with enterprises so that on their basis to organize long-term training to ensure the training of specialists in accordance with current industry standards.

Table 2. The matrix design process.

\begin{tabular}{|c|c|c|c|c|c|c|}
\hline & \multicolumn{4}{|c|}{ Providing sub-processes } & \multirow{2}{*}{\begin{tabular}{|c|}
$\begin{array}{c}\text { Assessment } \\
\text { of } \\
\text { competitors }\end{array}$ \\
$\begin{array}{c}\text { Competitiverent } \\
1\end{array}$ \\
\end{tabular}} \\
\hline $\begin{array}{c}\text { Provide } \\
\text { processes of }\end{array}$ & 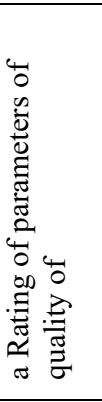 & 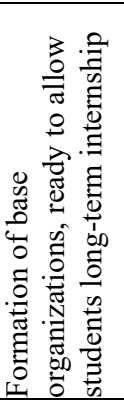 & 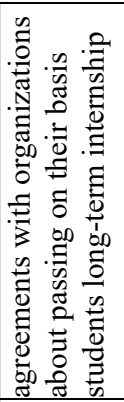 & 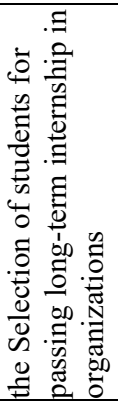 & 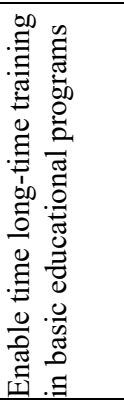 & \\
\hline $\begin{array}{l}\text { Practical } \\
\text { training of } \\
\text { students in } \\
\text { conditions of } \\
\text { mining } \\
\text { enterprises }\end{array}$ & 0,272 & $\mathrm{O}$ & $\odot$ & $\mathrm{O}$ & $\odot$ & 3 \\
\hline \multicolumn{2}{|c|}{$\begin{array}{l}\text { Significance of the } \\
\text { relationship }\end{array}$} & 0,816 & 2,448 & 0,816 & 2,448 & \\
\hline \multicolumn{2}{|c|}{ Options of sub-processes } & 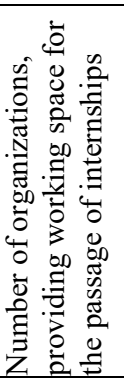 & 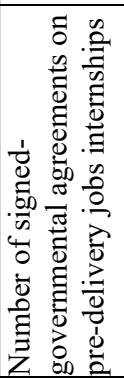 & 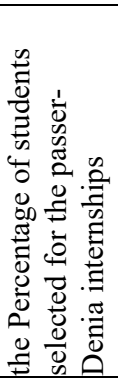 & 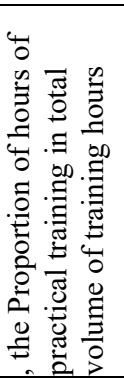 & \\
\hline \multicolumn{2}{|l|}{ Unit of measure } & units & units & units & $\%$ & \\
\hline \multicolumn{2}{|c|}{ The current value of the } & 270 & 10 & 1 & 1 & \\
\hline
\end{tabular}




\begin{tabular}{|l|c|c|c|c|}
\hline $\begin{array}{l}\text { parameters of the } \\
\text { subprocesses }\end{array}$ & 400 & 100 & 30 & 3 \\
\hline $\begin{array}{l}\text { Purpose of the } \\
\text { implementation subprocess }\end{array}$ & 4 & 5 & 7 & 7 \\
\hline $\begin{array}{l}\text { Level of difficulty } \\
\text { implementation targets } \\
\text { subprocesses }\end{array}$ & 4 & 5 & \\
\hline
\end{tabular}

In the next phase, "design production" - formulated tasks, rules, procedures, instructions, orders, develops job descriptions, regulations, educational, administrative and other processes of the University, selected equipment, operation, training materials, quality management tools, formed the basic educational programs of higher education and other components of the training of specialists with higher education.

\section{Conclusions}

Until recently, in the preparation of specialists for enterprises of the coal industry, the universities are not focused on meeting real needs and expectations of employers.

The use of the method Quality Function Deployment and consistent implementation in the educational process stages: "planning product", "product design", "designing process", "manufacturing engineering" allows to highlight the most important requirements of the employer to the quality of the products of the University for consideration and implementation at various stages of the process of preparing the human capital to work in the current economic conditions.

The implementation of the considered approach to construction of educational process increases the adaptive characteristics of the University and avoids (or at least minimize) the adjustments of quality of a product after its appearance on the labour market and, consequently, to provide its high value and at the same time relatively low cost, including through minimizing the costs of rework.

\section{References}

1. A. Toffler, The Third Wave (AST, 2010)

2. R. Kurzweil, The future of the world: a forecast up to the year 2099 (2016)

3. V. Mikhalchenko, I. Seredkina, E3S Web of Conferences 105, 04031 (2019)

4. L. P. Sullivan, Quality Function Deployment (1986)

5. James L. Brossert, Quality Function Deployment (Milwaukee, WI: ASQ Quality Press, 1990)

6. Akao Yoji, Ohfuji Tadashi, Naoi Tomoyoshi, Survey and Reviews on Quality Function Deployment in Japan (Tokyo: JUSE and IAQ, 1987)

7. V. Mikhalchenko, I. Seredkina, E3S Web of Conferences 1, 04005 (2017)

8. N. Kano, Guide to TQM in Service Industries (Asian Productivity Org, 1996)

9. J. Moorman, Leveraging the Kano Model for Optimal Results, Article No :882, October 9 (2012)

10. J. Marsh, The Continuous Improvement Toolkit (B. T. Batsford LTD - London, 1998) 